\title{
ASSESSMENT OF REPRESENTATIVE LANDSCAPE TYPES OF SKALICA DISTRICT
}

\author{
ALICA ŠEDIVÁ, ZITA IZAKOVIČOVÁ
}

Institute of Landscape Ecology, Slovak Academy of Sciences, Štefánikova 3, 81499 Bratislava, Slovak Republic; e-mail: alica.sediva@savba.sk, zita.izakovicova@savba.sk

\begin{abstract}
Šedivá A., Izakovičová Z.: Assessment of representative landscape types of Skalica district. Ekológia (Bratislava), Vol. 34, No. 4, p. 329-338, 2015.

Assessment of landscape quality is not possible without a good local landscape-ecological, social, economic and also political knowledge. When similar scientific researches and proposals for strategic development documents for municipalities and regions are needed, they have to come out mainly from scientific knowledge about unique and rare representative types of landscape. Implementation of a research module of the presented study entitled 'Assessment of representative landscapes of Skalica district' represents a complex example of a proposal on the methodical procedure of landscape-ecological analysis of Skalica district. Therefore, the core of this work lies in the detailed determination of the environmental quality of landscapes in Skalica district, which allowed us to evaluate the degree of environmental load and protection of each selected representative landscape type in the model area. This scientific knowledge is in continuation of the project complemented with opinions and attitudes of residents and key stakeholders about environmental, economic, cultural and social problems. The obtained knowledge can help towards optimal use of resources and potentials in the area and thus contribute to improving the overall quality of life in the monitored area.
\end{abstract}

Key words: landscape quality, representative landscape types, European Landscape Convention, coefficient of protection, coefficient of environmental load.

\section{Introduction}

European countries are developing dynamically in the sense of landscape changes. The character of many region specific landscape types are varying substantially and there are threatened by irreversible changes or by direct extinction. The result of this is that many rare and traditional landscape types have already disappeared. With them are lost pieces of cultural heritage of nations, a piece of their identity. Therefore, an important question is how to ensure the protection of natural, cultural and aesthetic values of these countries that exist under constant changes and pressures. Exactly these facts were the motivation for creating a document that forces us to think seriously about landscape, create greater unity of principles and ideals throughout Europe. The European Landscape Convention (ELC) is one of the first documents, which seek to strengthen the importance of landscape, its protection, management, planning and maintenance throughout the whole decision-making process on 
national and international levels. From the Convention (among others) for Slovakia and for other European countries that signed the document results the following tasks (Council of Europe, 2000):

- to identify own landscape types in the whole territory,

- to analyse their characteristics as well as forces and pressures that form them,

- to monitor their changes,

- to assess identified landscape types by taking into account the particular specific values that are assigned to them by interested parties and population.

Therefore, the main aim of this study is to develop, theoretically justify and experimentally verify a model of assessment of representative landscape types of Slovakia at the regional level.

Landscape typisation is a very often used method of spatial classification of landscape characteristics. The aim of typisation is in logical layout, synthesis and generalisation of sets of data about landscape characteristics, so that these allow the creation of a set of transparently and simply characterised spatial units that are possible to bound in a set area according to selected characteristics of landscape elements. The practical implication of typisation lies in that, for each typological unit, it is possible to create a whole set of specific characteristics, interpretations and evaluations, regardless of their actual occurrence. It is also possible to develop proposals for optimal use and management measures for landscape types (Bezák et al., 2010). After 2000, according to requirements based not only on the ELC, but even before its adoption, in Europe were developed a number of important international and national projects focussed on the development of typisation for separate landscapes (Bunce et al., 1996; Meeus, 1995; Mücher et al., 2005; Wascher, 2005; Lipský, Romportl, 2009; Antrop et al., 2002; Puschmann, 1998). All these typisations are based on a combination and synthesis of various thematic layers of geographical data (digital elevation model, geological subsoil, climate indicators, land cover, etc.). The key for successful typisation is in selection of the appropriate criteria for typisation.

\section{Material and methods}

The essence of this study is to present the methods of landscape typisation and evaluation of the quality of individual representative landscape types of the model region that contribute to the implementation and fulfilment of objectives of important documents about landscape, such as the ELC. The methodical procedure consisted of the following basic steps:

1. Definition and characterisation of representative landscape types at the regional level.

2. Evaluation of protection degree of individual representative landscape types.

3. Assessment of load degree of individual representative landscape types.

\section{Methodology of definition of representative landscape types in the model area}

The methodological procedure for the identification of representative landscape types is based on a methodology of typisation for the Slovak Republic, in particular on a work of researcher team Bezák et al.: Representative landscape types of Slovakia (2010) - this one is modified in our work according to the need at the regional level - selected units are mapped at a scale of 1: 50 000. Totally were identified 126 basic representative landscape types of Slovakia (RLTS). Each landscape type represents a unique combination of land use in different abiotic conditions.

In the district of Skalica predominates mainly plains and hills with different land use types pattern. In the model area were allocated 17 representative landscape types (Fig. 1). From these have the largest surface representation 
following ones:

- $\quad$ nuclear part of highlands (slopes and backs) with agricultural landscape with arable soil and forest land,

- $\quad$ wide river basins with mosaic of forests and arable soil,

- lowland polygenic hills and lower flat foothills with agricultural landscape with predominance of

- agricultural arable landscape,

- $\quad$ dune plains with agricultural landscape with predominance of vineyards.

Surface expression of individual representative landscape types of the model area is expressed in the following table.

T a b l e 1. Representative landscape types of Skalica district.

\begin{tabular}{|c|c|}
\hline Landscape type & Area (ha) \\
\hline Dune plains with continuously built-up area & 344.16 \\
\hline Dune plains with agricultural landscape with predominance of vineyards & 6744.94 \\
\hline Dune plains with agricultural landscape with predominance of arable soil & 812.21 \\
\hline $\begin{array}{l}\text { Dune plains with mosaic of arable soil, meadows, pastures, forests and } \\
\text { dispersed settlement }\end{array}$ & 1608.25 \\
\hline $\begin{array}{l}\text { Nuclear part of highlands (slopes and backs) with agricultural landscape with } \\
\text { arable soil and forest lands }\end{array}$ & $37,139.52$ \\
\hline $\begin{array}{l}\text { Nuclear part of highlands (slopes and backs) with forest land with mosaic of } \\
\text { arable soil, meadows and pastures }\end{array}$ & 500.25 \\
\hline $\begin{array}{l}\text { Nuclear part of highlands (slopes and backs) with partially forested land with } \\
\text { mosaic of arable soil }\end{array}$ & 1519.89 \\
\hline $\begin{array}{l}\text { Lowland polygenic hills and lower flat foothills with continuously built-up } \\
\text { area }\end{array}$ & 355.19 \\
\hline $\begin{array}{l}\text { Lowland polygenic hills and lower flat foothills with agricultural landscape } \\
\text { with predominance of arable soil, vineyards and dispersed settlement }\end{array}$ & 1074.07 \\
\hline $\begin{array}{l}\text { Lowland polygenic hills and lower flat foothills with agricultural landscape } \\
\text { with predominance of arable soil }\end{array}$ & $22,157.32$ \\
\hline $\begin{array}{l}\text { Lowland polygenic hills and lower flat foothills with agricultural landscape } \\
\text { with predominance of arable soil and vineyards }\end{array}$ & 579.98 \\
\hline Wide river basins with continuously built-up area & 478.05 \\
\hline $\begin{array}{l}\text { Wide river basins with agricultural landscape with mosaic of arable soil, } \\
\text { meadows and pastures }\end{array}$ & 742.81 \\
\hline Wide river basins with mosaic of forests and arable soil & $27,838.22$ \\
\hline $\begin{array}{l}\text { Undulating plains of river terraces and loess plateaus with continuously built- } \\
\text { up area }\end{array}$ & 89.11 \\
\hline $\begin{array}{l}\text { Undulating plains of river terraces and loess plateaus with predominance of } \\
\text { arable soil }\end{array}$ & 780.28 \\
\hline Wide river basins with predominance of agricultural arable landscape & 714.88 \\
\hline
\end{tabular}

Determination of coefficients of load and protection for representative landscape types of the model area

For evaluation of the landscape quality of individual representative landscape types of Slovakia was necessary an exact evaluation of the threat to individual types. Evaluation of the threat to selected representative types in the area due to their exposure to stress factors (both natural and anthropogenic) was carried out according to the coefficient of load (Miklós et al., 2006), which reflects an occurrence of the selected stressor in the area of RTLS and the intensity of its negative effects. 


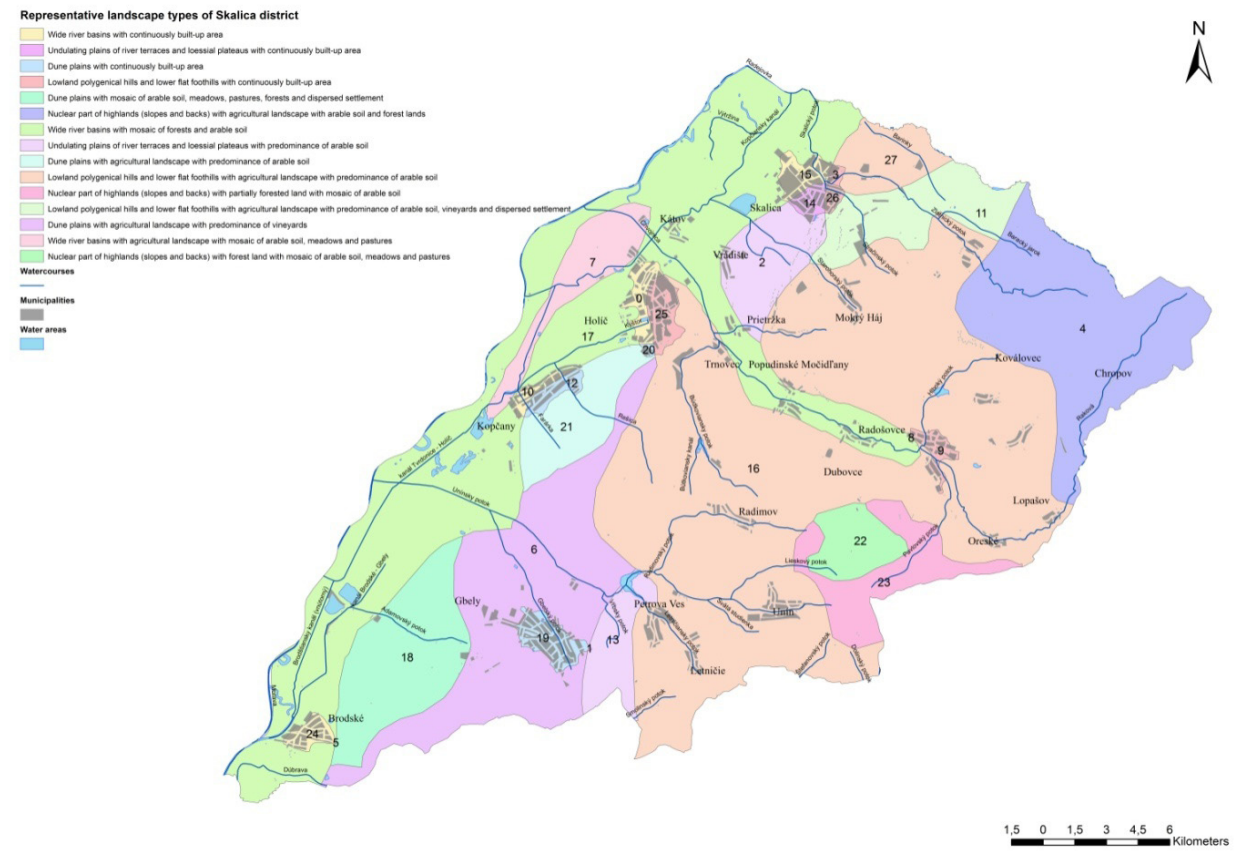

Fig. 1. Representative landscape types of Skalica district (author: Šedivá, 2015).

$$
K Z=\frac{\sum P S j x I S j}{p}
$$

$\mathrm{KZ}=$ coefficient of load of landscape type

PS $=$ area of stress factor

IS = coefficient of intensity of stress factors $\left(\mathrm{k}_{1}=0=\right.$ low intensity, $\mathrm{k}_{2}=0.5=$ medium intensity, $\mathrm{k}_{3}=1=$ high intensity)

$\mathrm{p}=$ area of landscape types

$\mathrm{j}=$ number of stress factors.

According to the stated coefficient, the territory was divided on areas that are medium, high and very high endangered (Figs 2, 3).

In terms of conservation of individual representative types in the studied area, it is also necessary to know the level of protection. The protection of these types was again evaluated according to precisely identified indicators coefficient of protection (Miklós et al., 2006). It describes proportion of the area of RLT of Skalica district, which falls under $2^{\text {nd }}$ to $5^{\text {th }}$ degree of protection (Fig. 4).

$$
K O=\frac{\sum p i}{p}
$$

$\mathrm{KO}=$ coefficient of protection

$\mathrm{p}_{\mathrm{i}}=$ surface area under protection $\left(_{\mathrm{i}}=2-5\right.$ degree of protection)

$\mathrm{p}=$ total area of landscape type.

For the purpose of processing map documents and defining coefficients was used software environment of programme GIS. A list of RLT of Skalica district and their characteristics are presented in Tables 1 and 2. 


\section{Results}

Individual RLT of the study area are threatened by the growing human activities and the impact of their accompanying negative response. Assessment of the threats of RLT due to their exposure to stress factors was realised according to the coefficient of threat, which reflects the occurrence of the selected stressor in a given area of RLT and the intensity of its negative effects (Miklós et al., 2006). This coefficient was calculated for the anthropogenic stress factors as well as for the natural stress factors in the area. The values of anthropogenic load coefficient reached much higher values than the natural load coefficient. These figures ranged from 6 to 10. The most endangered due to anthropogenic activities are dune plains - pláňavy (polygon Nos. 18, 5, 6 and 7) located in south-eastern part of the district) and wide river basins (polygon Nos. 7 and 17). Relatively high value of load (6.99) shows also RLT No. 4 the nuclear parts of highlands (slopes and backs) despite of fact that a significant part of the polygon belongs to the Protected Landscape Area Biele Karpaty - the Carpathians. The least threatened by anthropogenic stress factors is the central part of the study area (polygon Nos. 16 and 27), which base is created by lowland polygenic hills and lower flat foothills (see Fig. 2 ). An impressive fact is that the polygons, which are the most threatened by anthropogenic activities, are the least threatened by natural factors (polygon Nos. 7, 17 and 18), and vice versa RLT of Skalica district undisturbed by human activities is threatened due to its natural loads (polygon No. 16) (see Fig. 3).

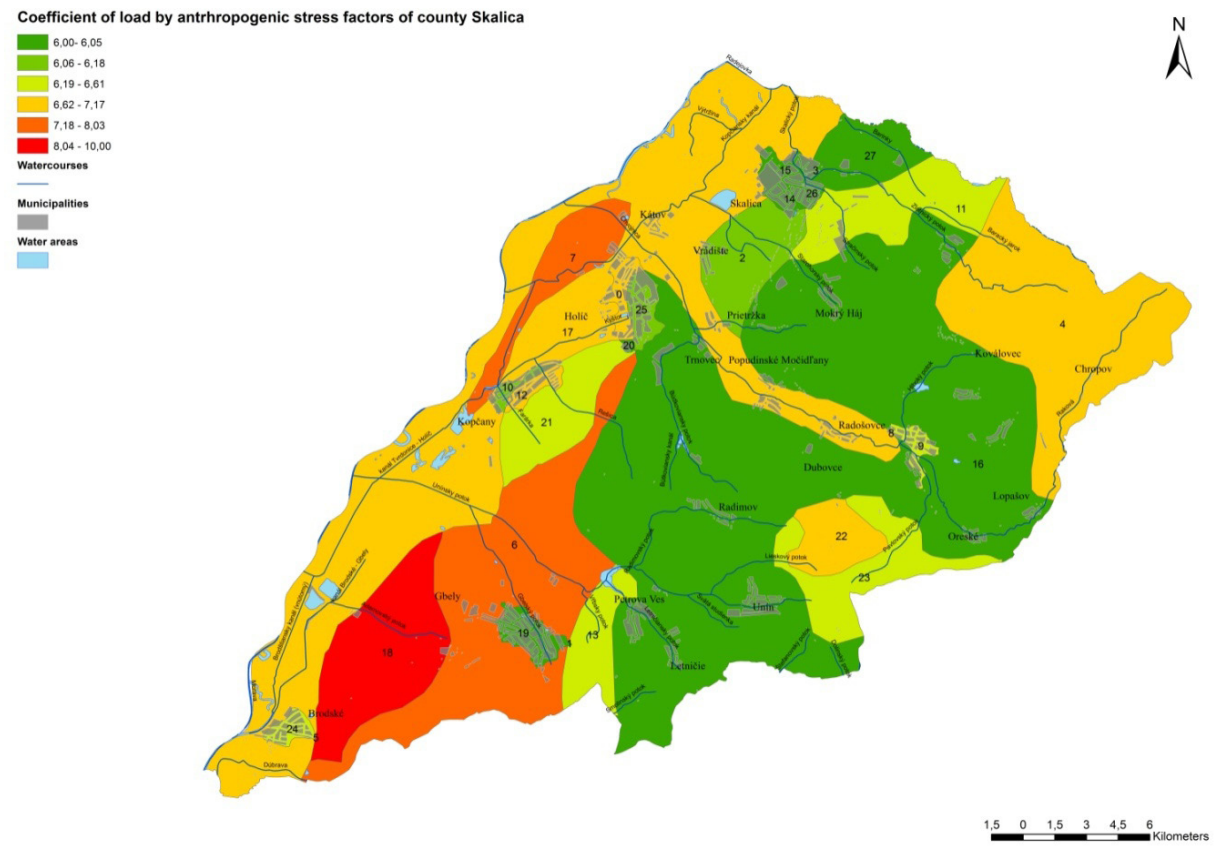

Fig. 2. Coefficient of load by anthropogenic stress factors (author: Šedivá, 2015). 


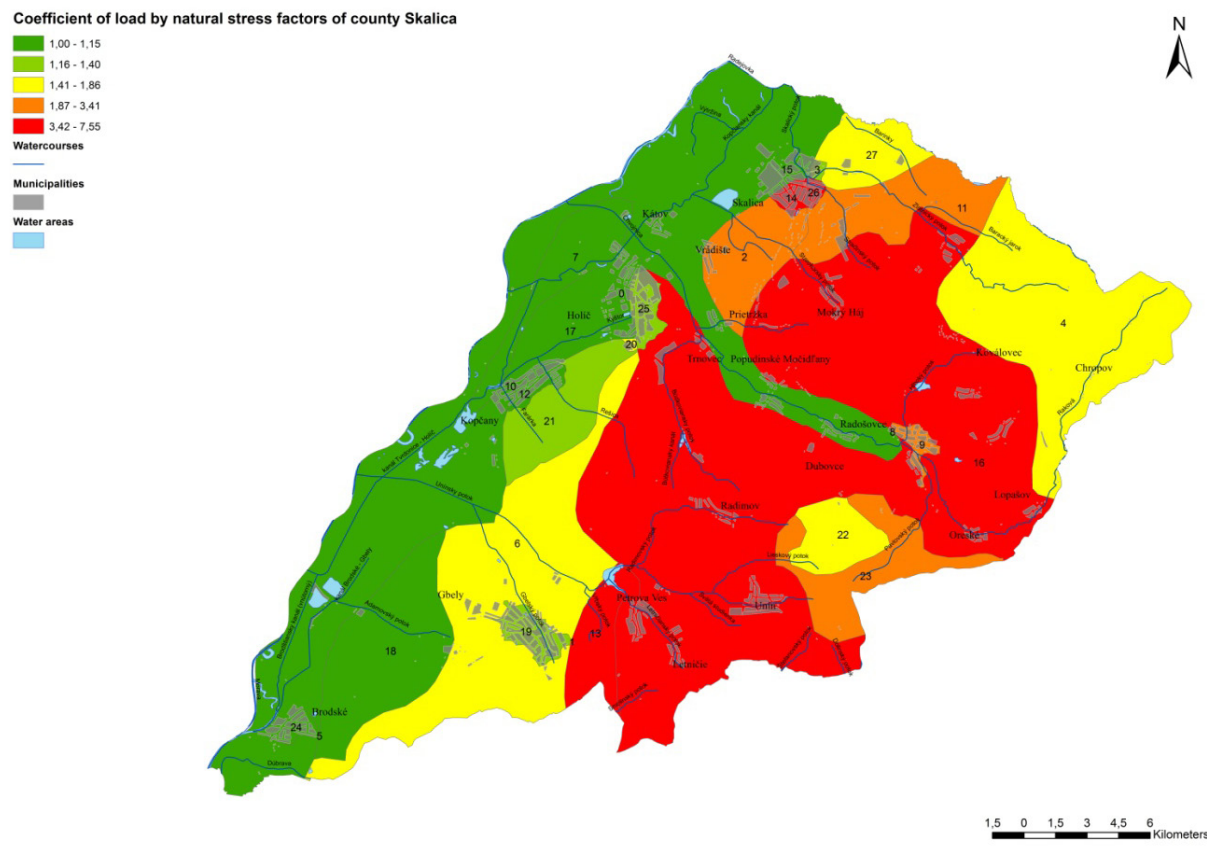

Fig. 3. Coefficient of load by natural stress factors (author: Šedivá, 2015).

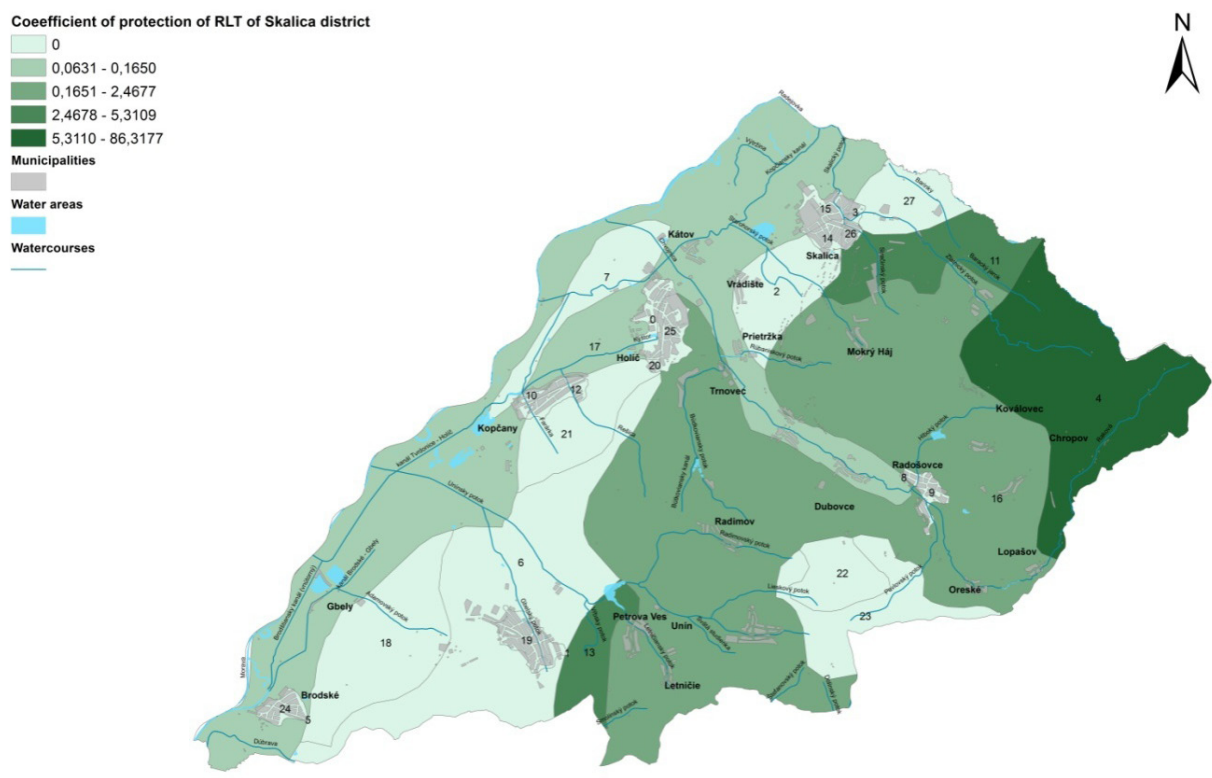

Fig. 4. Coefficient of protection of RLT of Skalica district (author: Šedivá, 2015). 
In terms of the preservation of individual representative landscape types, it is necessary to know the degree of protection. The protection of RLT was evaluated according to the coefficient of protection, which expresses the proportion of the surface area of RLT, which falls under the $2^{\text {nd }}$ to $5^{\text {th }}$ degree of protection (Miklós et al., 2006). Obviously, according to the calculated coefficient, the highest degree of protection is achieved in RLT No. 4 - the nuclear part of highlands (slopes and backs), which is a part of the Protected Landscape Area Biele Karpaty. A certain degree of protection is exhibited by polygons, in which are included small protected areas (RLT Nos. 6, 11, 16, 17 and 13) (see Fig. 4).

\section{Discussion and conclusion}

Countries that have signed and ratified the ELC are responsible for the classification and protection, as well as shaping the management policies that aim to maintain the highest diversity of landscapes and preserve the characteristic features of individual landscape types. When evaluating specific features, it is necessary to establish specific characteristics that distinguish certain type of landscape from other landscape types. The interaction of natural and cultural resources, particularly with people, is very important for landscape identification.

The classification and identification of landscape types is the first problem that has to be faced by organisations responsible for the development, protection and management of landscape. Base of an appropriate classification and identification of landscape types lies in the selection of an appropriate criteria for classification. The selection of available data is a very important step for classification on national and regional level (Swanwick, 2002; Mücher et al., 2005; Wascher, 2005). The selection of information databases reflects the purpose of classification but is very often limited by the availability of data and the format of required data. Some essential information about the natural and cultural environment thus remains insufficiently involved in the classification process, or they are not taken into account at all (e.g. humidity conditions, structure of landscape, aesthetic and spiritual elements etc.). A choice of input data is related to their pre-processing and generalisation that are also affected by a subjective view of a processor (Romportl, 2009). If a result of typisation should be a clear set of units with simple and concise characteristics of their properties, the generalisation of values of selected properties of elements is necessary. The generalisation process in general is based on "volume of the phenomenon", which, in particular, means extent and frequency of occurrence of certain values of selected landscape element. A problem can occur when some value of an element has a minor occurrence, but is significantly different (Bezák et al., 2010).

Selection of properties - the basic criteria of typisation, was during creation of typisations in individual European countries different. This selection of information databases was pre-conditioned mainly by the availability of required data and the purpose of processing of certain county typisation. Subjective attitude of a processor cannot be excluded. The United Kingdom has a long tradition in landscape classification (Bunce et al., 1996). The initial classification was based on the use of data from the primary and secondary landscape structures (in particular, a combination of data about land use, current and potential vegetation, soils, morphology of relief and later on, climate data). A similar classification principle for the selection of combinations of input data was used in other European countries like in the 


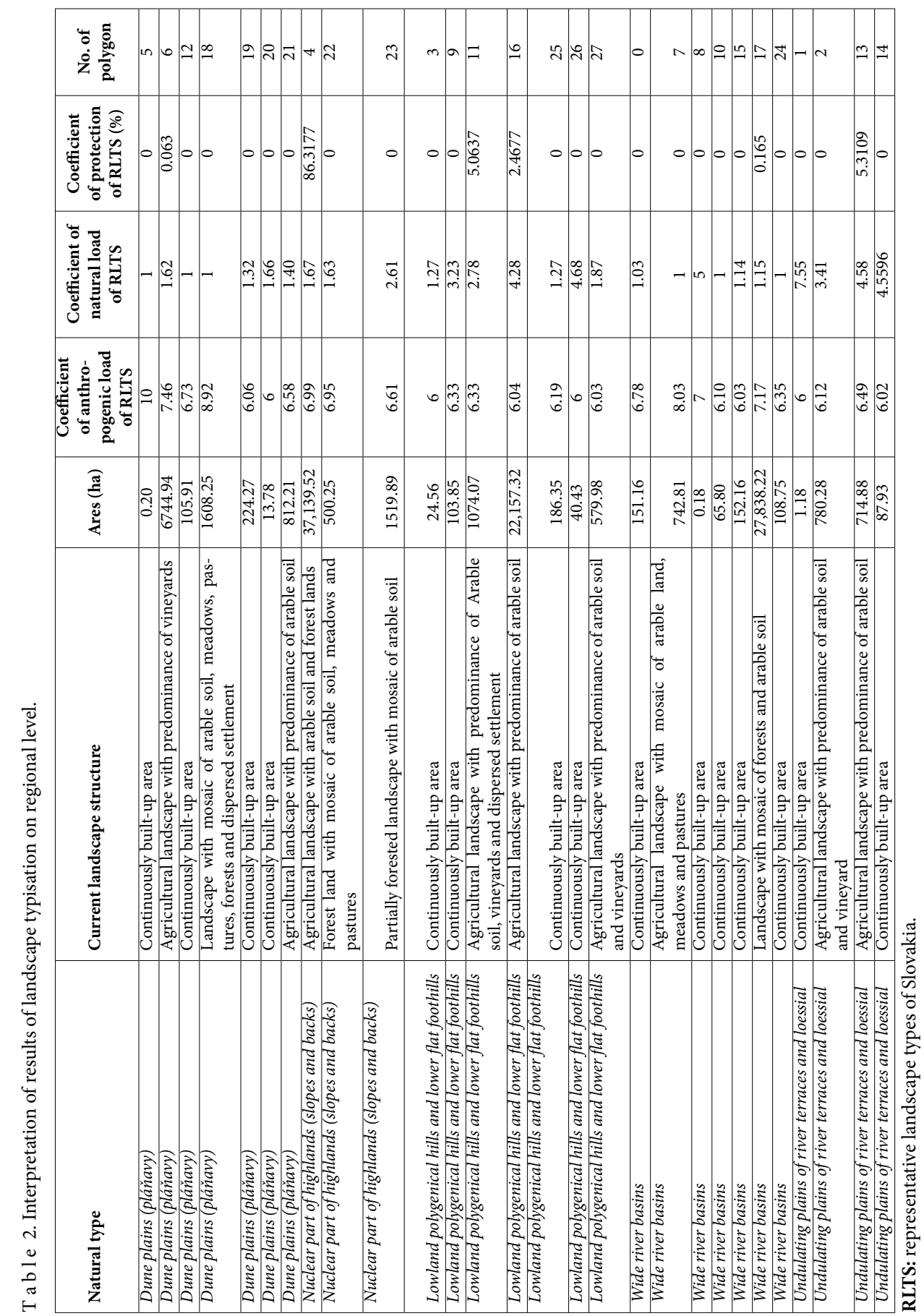


Netherlands (Meeuse, 1995), Belgium (Antrop, Van Eetvelde, 2002), Czech Republic (Lipský, Romportl, 2009), Hungary and Scandinavian countries. These classifications differ from each other by selection of input data from primary and secondary landscape structures and by a scale of processing. Compared to other mentioned landscape typisations is a process of typisation in Switzerland based on an entirely different principle. First, there were selected socalled mobile spatial units that used data about flora and fauna of the area. These were later on 'enriched' with aspect of cultural heritage of the country and with socio-economic parameters. Also, in Austria (Peterseil et al., 2004) was established a different system of selecting different types of cultural landscapes. At the beginning were defined physical geographical units depending on primary landscape structure, with later integration of secondary landscape structure. To final typisation were incorporated ethnical and political characteristics and also history of the country.

An impulse for developing of typisation of Slovakia and determination of its representative landscape types was a work of a research team from the Netherlands' Institute ALTERRA. The typisation of contemporary Slovak landscape represents a synthesis of information on natural environmental conditions and current land use. It is a synthesis of (loading) data layers from which each one represents a particular partial synthesis. Landscape typology has two information-methodological levels. The mentioned analytical-synthetic phase, where on the basis of superposition of maps and selected criteria are gained typological maps. Here is important a choice and combination of criteria. Following is a differential (distinguished), evaluation phase, where based on selected criteria is evaluated, sorted and classified the landscape and specified its characteristics.

\section{Conclusion}

The social demand for land is growing and a shift from functional images of nature and landscape towards more hedonistic vision occupies a central role. The development of each region is determined by the properties of its components (abiotic, biotic and socio-economic) as well as mutual relations and bonds acting among them. The individual landscape components are through their functional characteristics able to meet the development needs of human society and therefore act as resource of development of the society. The properties of these components determine the natural resources and the characteristics of socio-economic structure determine the dimensions of human, economic, cultural and historical resources. The characteristics and properties of these resources limit and restrict or encourage the development of various socio-economic activities, as on their basis, it is possible to state a development potential of different socio-economic activities (Izakovičová, 2003).

In the presented study, we introduced the concept of theoretical, methodological and practical processing of the topic of evaluation of representative landscape types of Skalica district, which is currently very relevant, in relation to a need of solving an issue of everincreasing socio-economic development and with them the associated unacceptable use of nature as a whole and its resources. This development must be necessarily in accord with landscape-ecological conditions, otherwise there arise problems of environment with impact on country and human health. 


\section{Acknowledgements}

The article is an output from the VEGA 2/0066/15 project: Green infrastructure of Slovakia.

\section{References}

Antrop, M., Van Eetvelde, V., Janssens, J., Martens, I. \& Van Damme S. (2002). Traditionele Landschappen van Vlaanderen. Ghent: Ghent University, Geography Department. http://www.geoweb.ugent.be/services/docs/ tradla.pdf>

Bezák, P., Izakovičová, Z., Miklós, L. et al. (2010). Reprezentatívne typy krajiny Slovenska.Bratislava: ÚKE SAV.

Bunce, R.G.H., Barr, C.J., Clarke, R.T., Howard, D.C. \& Lane A.M.J. (1996). Land classification forstrategic ecological survey. J. Environ. Manag., 47, 37-60. DOI: 10.1006/jema.1996.0034

Council of Europe (2000). Europe landscape convention [online]. [cit. 24.11.2014].http://www.coe.int/t/dg4/cultureheritage/heritage/landscape/default_EN.asp

Izakovičová, Z. (2003). Environmentálne limity regionálneho rozvoja. In M. Kozová \& Z. Bedrna (Eds.), Krajinnoekologické metódy v regionálnom environmentálnom hodnotení (pp. 95-103).Bratislava: Univerzita Komenského.

Lipský, Z. \& Romportl D. (2009). Typologie krajiny v České republice a zahraničí - stavproblematiky, metody a teoretická východiska. Geografie - Sborník ČGS, 112, 61-83.

Meeus, J.H.A. (1995). Pan-European landscapes. Landsc. Urban Plann., 31, 57-79. DOI: 10.1016/0169-2046(94)01036-8.

Miklós, L., Izakovičová, Z. et al. (2006). Atlas reprezentatívnych geosystémov Slovenska. Bratislava:ÚKE SAV.

Mücher, C.A., Garcia-Feced, C., Perez-Soba, M. \& Wascher D.M. (2005). Landscapes of Europe. In M. Perez-Soba \& D.M. Wascher (Eds.), Landscape character areas - places for buildingsustainable Europe (pp. vi+26). Oxford: Information Press.

Peterseil, J., Wrbka, T., Plutzar, C., Schmitzberger, I., Kiss, A., Szerencsits, E., Reiter, K., Schneider,W., Suppan, F. \& Beissmann H. (2004). Evaluating the ecological sustainability of Austrianagricultural landcapes - The SINUS approach. Land Use Policy, 21, 307-320. DOI: 10.1016/j.landusepol.2003.10.011.

Puschmann, O. (1998). The Norwegian landscape reference system. Use different sources to describe landscape regions. As (Norway): NIJOS.

Romportl, D. (2009). Typologie krajiny České republiky. Dizertačná práca, UK Praha.

Swanwick, C. (2002). Landscape character assessment. Guaidance for Englad and Scotland. The countrysides Agency, Scottish Naturale Heritage.

Wascher, D.M. (2005). European landscape character areas. Typologies, cartography and indicators for the assessment of sustainable landscapes. Wageningen: ELCAI, Landscape Europe, Alterra. 